\title{
EGFR NM_005228.3:c.2233_2247del15
}

National Cancer Institute

\section{Source}

National Cancer Institute. EGFR NM 005228.3:C.2233 2247del15. NCI Thesaurus. Code C98536.

A deletion of 15 nucleotides from the coding sequence of the EGFR gene from position 2233 through 2247. 